\title{
Perbedaan Jumlah Retikulosit Sebelum dan Sesudah Pemberian Tablet Tambah Darah
}

\section{Differences of Reticulocyte Count Before and After Iron-Tablets Administration}

\author{
Zefika Lutfi Ivana ${ }^{1} \&$ Lucia Sincu Gunawan*2 \\ ${ }^{1}$ Program Studi D3 Analis Kesehatan \\ ${ }^{2}$ Program Studi D4 Analis Kesehatan \\ Fakultas Ilmu Kesehatan, Universitas Setia Budi Surakarta, \\ Jl. Let. Jend. Sutoyo, Mojosongo, Surakarta, 57127, Jawa Tengah, Indonesia \\ *Corresponding author: sincugunawan@gmail.com
}

Received: Agustus 5, 2019; Revise: November 28, 2019; Accepted: December 7, 2019

DOI : https://doi.org/10.31001/biomedika.v12i2.593

\begin{abstract}
ABSTRAK
Anemia merupakan suatu keadaan dimana hemoglobin dan jumlah sel darah merah dalam tubuh kurang dari normal. Anemia defisiensi besi pada remaja putri perlu ditangani secara serius karena dapat menyebabkan gangguan perkembangan. Retikulosit merupakan parameter yang umum digunakan sebagai penentu keberhasilan terapi pada anemia defisiensi besi, yang menunjukkan respon fisiologis tubuh dengan meningkatkan produksi sel darah merah. Tujuan penelitian ini adalah untuk mengetahui perbedaan jumlah retikulosit sebelum dan sesudah pemberian tablet tambah darah pada mahasiswi Universitas Setia Budi Surakarta. Jenis penelitian ini adalah Randomized Control Trial, membagi kelompok secara acak menjadi kelompok kontrol dan kelompok perlakuan pemberian tablet tambah darah selama 7 hari. Subyek penelitian adalah 40 mahasiswi Universitas Setia Budi Surakarta. Pemeriksaan hitung retikulosit dilakukan di Laboratorium Hematologi Universitas Setia Budi, menggunakan perhitungan manual dengan pewarnaan supravital Briliant Cresyl Blue. Uji normalitas data dengan Saphiro Wilk dan uji beda dengan Independent $t$ Test dilakukan sebelum dan setelah pemberian tablet tambah darah 7 hari antara 2 kelompok. Uji beda jumlah retikulosit sebelum perlakuan pada kelompok perlakuan dan kontrol menunjukkan tidak ada perbedaan yang signifikan $(\mathrm{p}=0.084)$. Uji beda jumlah retikulosit menunjukkan perbedaan yang signifikan sesudah pemberian tablet tambah darah $(\mathrm{p}=0.005)$ antara kelompok kontrol dan kelompok perlakuan. Effect Size didapatkan hasil p=1.509 berarti bahwa efek dari pemberian tablet tambah darah tersebut cukup besar. Simpulan penelitian ini adalah adanya perbedaan yang signifikan jumlah retikulosit sebelum dan sesudah pemberian tablet tambah darah pada mahasiswi Universitas Setia Budi Surakarta. Pentingnya mengkonsumsi tablet tambah darah secara teratur sesuai anjuran minum untuk mencegah anemia pada wanita usia subur.
\end{abstract}

Kata Kunci: anemia; retikulosit; tablet tambah darah

\begin{abstract}
Anemia is a condition where the number of red blood cells in the body is not fulfilled. Iron deficiency anemia in young women has to be taken seriously because it can cause the development disturbance. Reticulocyte is a parameter commonly used to determine the success of therapy in iron deficiency anemia, which showed the body's physiologic response by enhancing the red blood cells production. This study aimed to find out the differences of reticulocyte count before and after administration of iron tablets on female students at Setia Budi University Surakarta. Using Randomized Control Trial, this study separated the subject randomly into control group and treatment group which received iron tablets for 7 days. The subjects were 40 female students at Setia Budi University in Surakarta. Reticulocyte count examination was carried out at the Setia Budi University Hematology Laboratory, using manual calculations with Brillant Cresyl Blue supravital staining. Data normality was tested with Saphiro Wilk
\end{abstract}


and Independent $t$ test were performed before and after 7 days administration of iron tablets between 2 groups. Reticulocyte count before supplementation in the treatment and control groups showed no significant difference $(p=0.084)$. After administration of iron tablets, reticulocyte count showed a significant difference $(p=0.005)$ between the control group and the treatment group. Effect Size exhibited $p=1.509$ which meant that the effect of iron tablets supplementation was quite large. This study concluded there were significant differences in the reticulocytes count before and after the administration of iron tablets to the students of Setia Budi University, Surakarta. It is very important to take iron tablets regularly at recommended dose to prevent anemia in women of childbearing age.

Keywords : anemia; reticulocyt; iron tablets

\section{PENDAHULUAN}

Anemia adalah suatu keadaan dimana kadar hemoglobin $(\mathrm{Hb})$ dalam darah kurang dari normal. Faktor-faktor penyebab anemia gizi besi adalah status gizi yang dipengaruhi oleh pola makanan, sosial ekonomi, lingkungan dan status kesehatan. Selain itu penyebab anemia gizi besi dipengaruhi oleh kebutuhan tubuh yang meningkat, akibat mengidap penyakit kronis dan kehilangan darah karena menstruasi dan infeksi parasit cacing (Masrizal, 2017).

Kekurangan zat besi menimbulkan gangguan atau hambatan dalam pertumbuhan baik sel tubuh maupun sel otak dan menyebabkan penurunan daya tahan tubuh. Hingga saat ini pencegahan dan penanggulangan anemia yang telah dilakukan ditujukan khususnya pada ibu hamil sedangkan pada remaja putri jarang diperhatikan. Anemia dapat dicegah maka konsumsi makanan yang kaya zat besi perlu dilakukan dan juga diimbangi dengan pemberian tablet zat besi (Fe) (Masrizal, 2007).

Anemia defisiensi besi merupakan masalah yang yang paling lazim di dunia dan menjangkit lebih dari 600 juta remaja. Di Indonesia anemia defisiensi besi pada remaja putri merupakan salah satu masalah gizi yang harus ditangani secara serius. Anemia defisiensi besi di Indonesia menjadi masalah kesehatan dengan prevelensi lebih dari 15\% (Ulfa, 2014).

Pada orang dewasa, sekitar 2 juta sel darah merah baru diproduksi setiap detik. Seiring dengan pematangan sel, diperlukan waktu beberapa hari untuk sel berisi hemoglobin ini menyingkirkan sisa RNA sitoplasma setelah nukleus dikeluarkan. Retikulosit ini sering dapat dibedakan pada apusan darah yang diwarnai Wright karena ukurannya yang besar dan warnanya keabu-abuan atau ungu. Retikulosit biasanya berada di darah selama 24 jam sebelum mengeluarkan sisa RNA dan menjadi sel darah merah (Sacher \& McPherson, 2000). Apabila retikulosit dilepaskan secara dini dari sumsum tulang, retikulosit imatur dapat berada di sirkulasi selama 2-3 hari. Pada pasien tanpa anemia hitung retikulositnya berkisar antara 1-2\%. Jumlah ini penting karena dapat digunakan sebagai indikator produktivitas dan aktivitas eritropoiesis di sumsum tulang dan membantu untuk menentukan klasifikasi. Retikulosit merupakan parameter yang umum digunakan untuk menilai keberhasilan terapi besi pada anemia defisiensi besi (Suega, 2000; Bakta, 2010). 
Menurut penelitian Franciska dan Max (Mantik, 2008) yang dilakukan pada 52 anak yang dibagi menjadi 2 kelompok, menyatakan bahwa perbedaan kadar retikulosit setelah penambahan suplemen zat besi pada kelompok 1 dan kelompok 2 tidak didapatkan perbedaan secara statistik $(\mathrm{p}<0,05)$ dengan median 0,10 . Namun hasil uji perbedaan kadar retikulosit sebelum dan sesudah pemberian tablet besi, vitamin A, dan mineral zinc memperlihatkan kenaikan retikulosit yang sangat bermakna $(\mathrm{p}<0,001)$ dengan median awal 0,950 dan median akhir 1,050.

Berbeda dengan penelitian yang sebelumnya, subyek penelitian adalah mahasiswi Universitas Setia Budi yang merupakan kelompok wanita usia subur yang aktif dan masih dalam perkembangan. Mahasiswi memiliki risiko anemia sangat tinggi karena tingkat aktivitas perkuliahan yang padat, pola makan yang tidak teratur, dan merupakan kelompok wanita yang mengalami menstruasi setiap bulannya. Penelitian ini juga memberikan terapi suplementasi tablet tambah darah selama 7 hari, dengan asumsi selama masa menstruasi. Berdasarkan uraian diatas, peneliti tertarik untuk melakukan penelitian "Perbedaan Jumlah Retikulosit Sebelum dan Sesudah Pemberian Tablet Tambah Darah Pada Mahasiswi Universitas Setia Budi Surakarta".

\section{METODE PENELITIAN}

Penelitian ini dilakukan secara Randomized Control Trial. Dilakukan pada Bulan Desember 2018 sampai Maret 2019, bertempat di Laboratorium Universitas Setia Budi Surakarta. Populasi dan sampel dalam penelitian ini 62 mahasiswi Universitas Setia Budi Surakarta yang memenuhi kriteria penelitian. Kriteria inklusi yaitu subyek bersedia untuk diambil darah, bersedia minum tablet tambah darah sesuai dengan ketentuan, berusia 20-30 tahun, kadar hemoglobin kurang dari $12 \mathrm{~g} / \mathrm{dl}$. Kriteria eksklusi yaitu subyek yang sedang mengalami menstruasi dan memiliki riwayat penyakit berat, sedang menderita sakit berat, setelah mendonorkan atau memperoleh transfusi. Dari hasil yang diperoleh, didapatkan 40 responden yang memenuhi kriteria. Selanjutnya dilakukan pembagian kelompok secara acak. Dari 40 responden dibagi menjadi kelompok kontrol sebanyak 20 responden dan kelompok perlakuan sebanyak 20 responden. Dilakukan pengambilan darah vena di hari pertama pada kedua kelompok untuk hitung retikulosit. Selanjutnya diberikan tablet tambah darah sebanyak 7 kapsul untuk di konsumsi selama 7 hari oleh responden kelompok perlakuan. Untuk responden kelompok kontrol tidak diberikan tablet tambah darah selama 7 hari. Kedua kelompok akan di follow up jumlah retikulosit pada hari ke tujuh .

\section{Alat dan Bahan}

Alat yang digunakan dalam penelitian ini : Mikroskop, Easy Touch Hemoglobinometer dengan strip reagennya, mikroskop. 
Bahan yang digunakan dalam penelitian ini adalah darah vena EDTA/ kapiler sebagai sampel pemeriksaan, pewarna BCB (Brilliant Cresyl Blue) dan tablet tambah darah dengan merk Novabion yang mempunyai komposisi tiap kapsul mengandung yang Ferro gluconate $250 \mathrm{mg}$, Vitamin C $50 \mathrm{mg}$, Asam Folat $1 \mathrm{mg}$, Vitamin B12 7,5 mcg, Cooper Sulfat 0,2 mg, Manganese Sulfate 0,2 mg dengan aturan minum : Sehari 1 kapsul setelah makan siang selama 7 hari.

\section{Prosedur Pemeriksaan Retikulosit}

a. Diteteskan 1 tetes larutan Brilliant Cresyl Blue (BCB) di tengah kaca objek

b. Ditteteskan 1 tetes darah vena EDTA/ kapiler di atas zat warna tadi dan segera campur darah dengan zat warna segera dicampur dengan memakai sudut kaca objek lain.

Selama periode penelitian yang dilakukan pada mahasiswi Universitas Setia Budi Budi Surakarta didapatkan 40 probandus yang bersedia dan sesuai dengan kriteria inklusi dan eksklusi.

Tabel 1 dan 2 menyajikan data deskriptif pengukuran jumlah retikulosit pada kelompok kontrol dan kelompok perlakuan yang terdistribusi sebagai berikut: pada kelompok kontrol hari ke-0 c. Tetesan darah itu ditutup dengan kaca penutup. Lapisan darah dalam sediaan basah ini harus benar-benar tipis.

d. Sediaan dibiarkan beberapa menit atau masukkan kedalam cawan petri yang berisi kertas saring basah.

e. Sediaan diperiksa dengan pembesaran objektif 100x

f. Ditentukan berapa banyak retikulosit didalam 1000 eritrosit (Gilang, 2017).

\section{Analisis Data}

Data penelitian ini dianalisis dengan analisis statistik deskriptif untuk karakteristik sampel dan dilanjutkan dengan Independent sampel t-test dan Effect Size.

\section{HASIL DAN PEMBAHASAN}

memiliki rerata jumlah retikulosit sebesar $1.15 \pm 0.22 \%$, pada hari ke-7 memiliki rerata jumlah retikulosit sebesar $1.29 \pm 0.14 \%$. Jumlah retikulosit pada kelompok perlakuan sebelum pemberian tablet tambah darah memiliki rerata jumlah retikulosit awal $1.30 \pm 0.31 \%$, sesudah pemberian tablet tambah darah memiliki rerata $1.50 \pm 0.28 \%$.

Tabel 1. Jumlah Retikulosit pada Kelompok Kontrol

\begin{tabular}{ccc}
\hline Jumlah Retikulosit & \multicolumn{2}{c}{ Kelompok Kontrol } \\
\cline { 2 - 3 } & Hari ke-0 & Hari ke 7 \\
\hline Rerata & 1,15 & 1,29 \\
Standart Deviasi & 0,22 & 0,14 \\
Minimum & 0,80 & 0,98 \\
Maksimum & 1,51 & 1,29 \\
\hline
\end{tabular}


Tabel 2. Retikulosit pada Kelompok Perlakuan

\begin{tabular}{ccc}
\hline Jumlah Retikulosit & \multicolumn{2}{c}{ KelompokPerlakuan } \\
\cline { 2 - 3 } & Hari ke-0 & Hari ke 7 \\
\hline Rerata & 1,30 & 1,50 \\
Standart Deviasi & 0,31 & 0,28 \\
Minimum & 0,72 & 0,97 \\
Maksimum & 1,77 & 1,93 \\
\hline
\end{tabular}

Uji Normalitas

Sebelum dianalisis data, dilakukan uji normalitas. Hal ini untuk mengetahui apakah data yang diperoleh berasal dari populasi terdistribusi normal atau tidak. Uji normalitas menggunakan uji Saphiro Wilk karena sampel yang digunakan kurang dari 50. Tabel 3 menyajikan hasil uji normalitas terhadap beberapa variabel penelitian yang menunjukkan $\mathrm{p}>0.05$ yang berarti data terdistribusi normal. Variabel tersebut meliputi jumlah retikulosit pada kelompok kontrol dan perlakuan

Tabel 3. Uji Normalitas Data

\begin{tabular}{ccc}
\hline \multirow{2}{*}{ Jumlah Retikulosit } & $\begin{array}{c}\text { Kelompok } \\
\text { Perlakuan }\end{array}$ & $\begin{array}{c}\text { Kelompok } \\
\text { Kontrol }\end{array}$ \\
\cline { 2 - 3 } & \multicolumn{2}{c}{ Sig (2-tailed) } \\
\hline Hari ke-0 & 0,17 \\
Hari ke-7 & 0,42 & \\
Hari ke-0 & & 0,19 \\
Hari ke-7 & & 0,26 \\
\hline
\end{tabular}

\section{Uji Independent t-Test}

Pada kelompok kontrol dan perlakuan, sebelum pemberian tablet tambah darah dilakukan analisis uji $\mathrm{t}$ sampel tidak berpasangan dari data jumlah retikulosit hari ke-0 diperoleh nilai $\mathrm{p}=0.084$ yang menujukkan tak ada perbedaan yang signifikan antara 2 kelompok (Tabel 3). Pada hari ke-7 hasil pemeriksaan uji retikulosit kedua kelompok dilakukan uji beda $\mathrm{t}$ sampel tidak berpasangan dan diperoleh nilai $\mathrm{p}=0.005(\mathrm{p}<0.05)$ yang berarti terdapat perbedaan yang bermakna terhadap hasil rerata jumlah retikulosit sebelum dan sesudah pemberian tablet tambah darah.

Tabel 3. Hasil Uji Independent Sampel t-Test Jumlah Retikulosit pada Kelompok Kontrol dan Kelompok Perlakuan

\section{Pemberian Terapi}

Sig 2 tailed

\begin{tabular}{ll}
\hline Hari ke-0 & 0.084 \\
Hari ke-7 & 0.005
\end{tabular}




\section{Uji Effect Size}

Merupakan cara sederhana untuk mengkuantifikasikan besarnya perbedaan mean antara dua kelompok, melihat efektivitas suatu intervensi relatif dibandingkan dengan kontrol (Murti, 2018)

$$
\begin{aligned}
\text { Effect Size } & =\frac{\text { Mean Kelompok Perlakuan -Mean Kelompok Kontrol }}{\text { Standar Deviasi }} \\
& =\frac{1,5060-1,2905}{0.14274} \\
& =1,509
\end{aligned}
$$

Ketentuan : nilai rujukan -4 sampai 4

Pada hasil penelitian ini, didapatkan hasil uji Effect Size yaitu $\mathrm{p}=1.509$, sehingga dapat dinyatakan bahwa efek dari pemberian tablet tambah darah tersebut cukup besar. Program pencegahan dan penanggulangan terjadinya anemia pada remaja selama ini berupa pemberian tablet tambah darah perlu digalakkan. Pemberian tablet tambah darah efektif digunakan untuk menghindari terjadinya anemia terutama anemia defisiensi besi. Wanita usia subur seperti mahasiswi merupakan sasaran yang sangat mudah terkena anemia defisiensi besi. Banyaknya aktivitas, saat menstruasi, konsumsi makanan yang kurang bergizi dan tidak tercukupinya kebutuhan besi harian merupakan faktor yang dapat menyebabkan tubuh kehilangan cukup banyak besi dan menyebabkan anemia. Kurangnya kesadaran akan pentingnya konsumsi tablet tambah darah terutama saat menstruasi juga merupakan faktor terpenting. Suplemen penambah darah merupakan obat yang mengandung multivitamin dan zat besi yang sering digunakan untuk mencukupi kebutuhan vitamin serta zat besi yang tidak didapatkan dari makanan. Hal ini perlu diperhatikan mengingat dampak anemia dapat menjadi sangat berbahaya bagi tubuh.
Dalam kondisi normal jumlah retikulosit dalam sumsum tulang adalah sama dengan retikulosit yang ada dalam peredarah darah. Karena masa hidup normal atau waktu kelangsungan hidup eritrosit adalah 120 hari, maka 1/120 hari jumlah eritrosit hilang setiap hari, dan retikulosit dalam jumlah yang sama dilepaskan kedalam sirkulasi. Dipengaruhi oleh eritropoietin, jumlah retikulosit premature yang dilepaskan dari sumsum tulang akan meningkat. Jumlah retikulosit yang meningkat sebagai indikasi dari umur eritrosit yang menjadi lebih pendek dibandingkan normal yang didasarkan terhadap menurunnya jumlah eritrosit total. Menurunnya jumlah retikulosit dapat disebabkan oleh umurnya lebih pendek atau menurunnya produksi. Retikulositosis menunjukkan bahwa tubuh sedang berusaha untuk mempertahankan homeostatis. Jumlah retikulosit yang dinyataan sebagai presentasi dari jumlah sirkulasi eritrosit (Kiswari, 2014).

Hitung jumlah normal retikulosit adalah 0,5-2,5\% dari jumlah absolute 25$125 \times 10^{9} / 1$. Jumlah ini seharusnya meningkat pada anemia karena terjadinya peningkatan eritropoietin dan makin tinggi jika anemia makin berat. Hal ini jadi nyata bila sudah ada waktu untuk terjadinya 
hyperplasia eritroid di sumsum tulang seperti pada hemolisis kronik. Setelah perdarahan berat akut, terdapat respon eritropoietin di sumsum tulang seperti pada hemolisis kronik. Setelah pendarahan berat akut, terdapat respon eritropoietin dalam 6 jam, hitung retikuosit meningkat dalam 2-3 hari, mencapai maksimum dalam 6-10 hari, dan tetap tinggi sampai kadar hemoglobin kembali normal. Hasil hitung retikulosit pada pasien anemia yang tidak meningkat menunjukkan terganggunya fungsi sumsum tulang atau kurangnya rangsangan eritropoietin (Hoffbrand \& Pettit, 2005).

Hitung retikulosit yang meningkat pada kadar hemoglobin yang normal menunjukkan bahwa sel darah merah sedang mengalami kerusakan atau hilang, tetapi sumsum tulang telah meningkatkan produksi eritrosit untuk mengkompensasi kebutuhan tubuh. Pada kadar hemoglobin yang rendah, hitung retikulosit $0,5 \%$ sampai $2,5 \%$ mengisyaratkan bahwa respon terhadap anemia tidak memadai. Hal ini dapat terjadi akibat gangguan atau penurunan produksi sumsum tulang atau penurunan kadar eritropoietin. Apabila seseorang mengidap anemia, jumlah eritrosit yang beredar turun sehingga presentasi retikulosit "normal" $(0,5 \%$ $2,5 \%$ ) akan meningkat. Pada defisiensi besi, terutama pada anemia akibat pengeluaran darah berkepanjangan, pemberian terapi besi menghasilkan respons retikulosit dalam 4 sampai 7 hari. Beberapa literatur menyebutkan kadar maksimal retikulosit tercapai pada hari ke 5-7 setelah terapi. (Sacher \& Mc.Pherson, 2002).

Berdasarkan hasil penelitian dari 5 orang pendonor terhadap gambaran jumlah retikulosit sebelum dan setelah donor darah di UDD PMI Kabupaten
Majalengka didapatkan hasil $100 \%$ mengalami peningkatan retikulosit (Liswanti, 2015). Penelitian yang serupa dilakukan Nurjanah (2017) hasil pemeriksaan dari 27 responden keseluruhan mengalami peningkatan jumlah retikulosit sesudah menstruasi. Rata-rata jumlah retikulosit sebelum menstruasi adalah $1,4 \%$ dan sesudah menstruasi yaitu $1,9 \%$, sehingga peningkatan sebesar $0,5 \%$.

\section{KESIMPULAN}

Terdapat perbedaan yang bermakna jumlah retikulosit sebelum dan setelah pemberian tablet tambah darah pada mahasiswi Universitas Setia Budi $(\mathrm{p}=0.005)$.

\section{DAFTAR PUSTAKA}

Bakta, K. S. 2010. Aplikasi Klinis Retikulosit. Jurnal Penyakit Dalam, 11, 191-201.

Gilang, N. 2017. Panduan Pemeriksaan Laboratorium Hematologi Dasar. Jakarta: CV. Trans Info Media

Handayani, W., \& Haribowo, A. 2008. Buku Ajar Asuhan Keperawatan pada Klien dengan Gangguan Sistem Hematologi. Jakarta: Salemba Medika.

Hoffbrand, A. V., \& Pettit, J. E. 2005. Kapita Selekta : Hematologi (Essential Haematology). Jakarta: Buku Kedokteran EGC.

Kiswari, R. (2014). Hematologi dan Transfusi . Jakarta: Erlangga.

Liswanti, Y, Nur Arifah, F. 2015. Gambaran Jumlah Retikulosit Sebelum Dan Setelah Donor Darah. Jurnal Kesehatan Bakti Tunas Husada Volume 13 Nomor 1 Februari 2015, 118

Mantik, M. 2008. Efektivitas Penambahan Seng dan Vitamin A pada Pengobatan Anemia Defisiensi Besi. 10(1), 24-28. 
Masrizal. 2007. Anemia Defisiensi Besi. Jurnal Kesehatan Masyarakat, 140-145.

Murti, B. 2018. Prinsip dan Metode Riset Epidemiologi. Edisi 5. Karanganyar : Bintang Fajar Offset

Nurjanah, S, Ariyanto, T, Santosa, B. 2017. Perbedaan Jumlah Retikulosit Sebelum Dan Sesudah Menstruasi. http://digilib.unimus.ac.i/files//disk1/144/jt ptunimus-gdl-sitinurjan-7167-1abstrak.pdf (didownload 4 Agustus 2019)
Sacher, R. A \& Mc.Pherson, R.A. 2002. Tinjauan Klinis Hasil Pemeriksaan Laboratorium. Jakarta: EGC

Ronald, A. S., \& Richard, A. M. 2000.Tinjauan Klinis Hasil Pemeriksaan Laboratorium. Jakarta : EGC.

Suega, K. 2000. Aplikasi Klinis Retikulosit, 191201.

Ulfa, E.S. 2014. Hubungan Perilaku Minum Tambel Zat Besi Pada Remaja Putri Dengan Kadar Hemoglobin. Jurnal Ners dan Kebidanan , 1, 57-61. 